\title{
UJI POTENSI HEMOSTASIS EKSTRAK ETANOL DAUN KEJI BELING (Strobilanthes crispus) PADA MENCIT (Mus musculus)
}

\author{
Istiyani*, Nur Mita, Muhammad Amir Masruhim \\ Laboratorium Penelitian dan Pengembangan FARMAKA TROPIS \\ Fakultas Farmasi Universitas Mulawarman, Samarinda, Kalimantan Timur \\ *Email: Istiyani@ymail.com
}

\begin{abstract}
ABSTRAK
Daun keji beling memiliki banyak kandungan senyawa yang bermanfaat, salah satunya adalah tannin yang efektif untuk menghentikan pendarahan (hemostasis). Tujuan dari penelitian ini adalah untuk mengetahui dosis terbaik dan potensi ekstrak etanol daun keji beling dibandingkan dengan kontrol positif pada mencit. Penelitian ini menggunakan lima kelompok mencit sebagai sampel terdiri dari lima mencit tiap kelompok. Waktu pendarahan ditentukan dengan metode bleeding tail. Didapatkan hasil bahwa nilai rata-rata waktu perdarahan pada kontrol negatif sebesar $99.111 \pm 0.832$ detik; kontrol positif sebesar $92.222 \pm 7.952$ detik; ekstrak etanol daun keji beling dosis A sebesar $94.111 \pm 5.508$ detik; dosis B sebesar 88,611 $\pm 9,425$ detik; dosis C sebesar 91,333 \pm 7,498 detik. Data dianalisis dengan menggunakan Anava Dua Arah dan menunjukkan bahwa ada perbedaan yang signifikan dari waktu perdarahan antara kelompok kontrol negatif, kelompok kontrol positif dan kelompok uji ekstrak etanol daun keji beling. Kesimpulan dari penelitian ini adalah ekstrak etanol daun keji beling dapat memperpendek waktu pendarahan pada mencit serta memiliki potensi yang sama baiknya dengan kontrol positif, dimana dosis B merupakan dosis terbaik.
\end{abstract}

Kata Kunci : Daun keji beling, waktu perdarahan, hemostasis

\begin{abstract}
Keji beling leaves have many benefits compounds, as an effective tannin to stop bleeding (hemostasis). The purpose of this study was to knowthe best dose and the potential of ethanol extract of keji beling leaves when compared with positive control in mice.This study was using five groups of mice as a sample consist of five mice per group. Bleeding time was determined by bleeding tail method.The result showed that mean value of bleeding time of negative control is $99.111 \pm 0.832$ seconds; positive control is $92.222 \pm$ 7952 seconds; ethanol extract of krji brling leaves dose A is $94.111 \pm 5.508$ seconds; dose $\mathrm{B}$ is $88.611 \pm 9.425$ seconds; dose $\mathrm{C}$ is $91.333 \pm 7.498$ seconds. Data were analyzed withTwo-Way Anova and showed that there is a significant difference of the bleeding time between the negative control group, positive control group and the test group of ethanol extract of keji beling leaves. The conclusion of this study is the ethanol extract of keji beling leavescan make shorter bleeding time in mice and have the potential as good as with positive control, in which the dose of B is the best dose.
\end{abstract}

Key words : Keji beling leaves, bleeding time, hemostasis 


\section{PENDAHULUAN}

Perdarahan merupakan suatu proses keluarnya darah dari pembuluh darah akibat rusaknya dinding pembuluh darah karena trauma atau penyakit. Perdarahan memerlukan penanganan khusus, sebab perdarahan yang berlangsung lama dan tidak segera ditangani dapat menyebabkan syok, sinkop dan bila lebih lanjut dapat menyebabkan kematian (Setiadinata, 2003).

Perdarahan merupakan komplikasi yang sering terjadi setelah suatu tindakan pembedahan. Waktu perdarahan adalah interval waktu dari tetes darah pertama sampai darah berhenti menetes (Vogel, 2002). Waktu perdarahan merupakan salah satu parameter pengukuran pembekuan darah untuki mengetahui proses vasokontriksi pada fase vaskular dan pembentukan sumbat hemostatik sementara pada fase platelet dalam proses hemostasis (Sukandar, 2008).

Tindakan-tindakan lokal sebaiknya diaplikasikan untuk menghentikan perdarahan, seperti penekanan oklusal menggunakan kasa yang merupakan satu tindakan untuk mengontrol perdarahan dan dapat merangsang pembentukan bekuan darah yang stabil (Pedersen, 1996). Selain tindakan lokal, diperlukan juga tindakan secara sistemik. Salah satunya dengan pemberian sediaan hemostatik secara oral maupun injeksi. Sediaan hemostatik dapat membantu mempertahankan volume plasma dan memperbaiki tekanan darah (Setiadinata, 2003).

Khasiat hemostatik bukan hanya terdapat pada obat-obat sintetik, tetapi beberapa tumbuhan juga memiliki khasiat hemostatik. Di Indonesia terdapat beberapa tumbuhan yang merupakan tanaman obat yang memiliki khasiat hemostatik. Salah satu tanaman obat yang dikenal masyarakat dapat menghentikan perdarahan yaitu keji beling (Strobilanthes crispus). Masyarakat biasanya menggunakan bagian daun keji beling sebagai obat luka dengan cara ditumbuk dan ditempelkan langsung kedaerah luka atau dengan cara merebus daun keji beling dan air rebusannya digunakan untuk membersihkan luka.

Ekstrak daun keji beling mengandung sejumlah besar senyawa aktif seperti mineral (potassium, kalsium, sodium, kalium, besi dan fosfor), vitamin larut air (C, B1 dan B2), vitamin E, katekin, alkaloid, kafein, tannin, kumarin, flavonoid dan steroid (Setyaningsih, 2008). Menurut Li, et al (2011) kandungan tannin dan flavonoid pada ekstrak keji beling (Strobilanthes crispus) mempunyai efek terhadap kecepatan proses penyembuhan luka dengan cara mengurangi radikal bebas pada area luka, meningkatkan kontraksi jaringan, meningkatkan pembentukan pembuluh kapiler dan peningkatan proliferasi fibroblas.

Beberapa penelitian menunjukkan bahwa ekstrak daun keji beling (Strobilanthes crispus) berpengaruh pada proses penyembuhan luka. Pemberian ekstrak daun keji beling (Strobilanthes crispus) secara topical pada tikus yang telah dilakukan eksisi pada daerah leher menunjukkan proses penyembuhan luka yang lebih cepat dibandingkan dengan kelompok tanpa perlakuan. Hal tersebut dinilai secara klinis dari penutupan luka dan secara histology dari jaringan granulasi dimana pada kelompok perlakuan didapatkan penurunan sel inflamasi, peningkatan sabut kolagen, fibroblas dan kapiler darah (AlHenhena et al, 2011).

Berdasarkan hal tersebut, peneliti tertarik untuk menguji aktivitas hemostasis dari daun keji beling terhadap waktu pemberhentian darah pada mencit putih (Mus musculus) yang dilukai pada bagian ekornya. 


\title{
METODE PENELITIAN
}

\section{Waktu dan Tempat Penelitian}

Penelitian dilakukan selama 3 bulan dari bulan November 2015 sampai Februari 2016. Penelitian dilakukan di Laboratorium Penelitian Fakultas Farmasi Universitas Mulawarman.

\begin{abstract}
Alat dan Bahan
Alat yang digunakan dalam penelitian ini yaitu kandang hewan coba berupa box plastik berukuran $55 \times 40 \times 20 \mathrm{~cm}$ sebanyak 5 buah dan di atasnya diberi penutup berupa jaring-jaring yang terbuat dari kawat serta di beri alas sekam kayu, tempat makanan dan botol minuman mencit, holder mencit, gunting bedah, labu ukur, gelas kimia, mortar dan stamper, rotary evaporator, sonde dan spoit, tombangan analitik, toples kaca, water bath dan kamera digital. Bahan yang digunakan dalam penelitian ini yaitu makanan mencit (pellet), air putih untuk minuman mencit, daun keji beling segar dari Kelurahan Tanah Merah Samarinda, larutan etanol 96\%, larutan alcohol 70\%aquades, obat asam traneksamat, kertas saring dan NaCMC.
\end{abstract}

\section{Metode Penelitian}

Penelitian ini merupakan penelitian eksperimental dengan desain uji secara acak yang dibandingkan dengan kontrol. Penelitian ini menggunakan lima kelompok mencit sebagai sampel yakni kelompok kontrol positif, kontrol negatif dan 3 kelompok uji dengan 3 variasi dosis yakni Dosis A, Dosis B dan Dosis C dimana tiap kelompok terdiri dari lima mencit tiap kelompok.

\section{Prosedur Kerja}

\section{Pengambilan Sampel}

Daun keji beling (Strobilanthes crispus) yang digunakan dalam penelitian ini adalah daun yang sudah tua, masih segar dan bebas hama yang diambil langsung dari Kelurahan Tanah Merah Samarinda. Kemudian ditimbang daun keji beling (Strobilanthes crispus) segar yang didapat.

\section{Preparasi Sampel}

Daun keji beling (Strobilanthes crispus) yang telah dicuci, dipotong-potong atau dirajang dan dikering-anginkan selama 14 hari hingga benar-benar kering. Daun keji beling (Strobilanthes crispus) yang telah dikeringkan kemudian ditimbang dan di haluskan dengan blender hingga terbentuk simplisia.

\section{Ekstrasi Daun Keji Beling (Strobilanthes crispus)}

Simplisia daun keji beling (Strobilanthes crispus) ditimbang dan dimaserasi dengan etanol teknis $96 \%$ selama 3 X 24 jam dengan pengadukan beberapa kali, lalu disaring dan ampasnya direndam kembali dengan pelarut yang baru, hasil penyarian (filtrat) yang diperoleh dievaporasi mengggunakan rotary evaporator sehingga diperoleh ekstrak kental.

\section{Pembuatan Larutan Ekstrak Daun Keji Beling (Strobilanthes crispus)}

Ekstrak kental daun keji beling (Strobilanthes crispus) dibuat dengan dosis $20 \mathrm{mg} /$ $20 \mathrm{~g} \mathrm{BB}, 40 \mathrm{mg} / 20 \mathrm{~g} \mathrm{BB}$, dan $60 \mathrm{mg} / 20 \mathrm{~g} \mathrm{BB}$ dengan cara membaut larutan stok dengan konsentrasi $60 \mathrm{mg} / 20 \mathrm{~g}$ BB dengan menimbang ekstrak kental sebanyak $1800 \mathrm{mg}$ dilarutkan dalam $10 \mathrm{~mL} \mathrm{NaCMC} \mathrm{0,5 \%}$ 


\section{Pembuatan Suspensi NaCMC 0,5\% dan Suspensi Obat Asam Tranesksamat}

Dibuat suspensi NaCMC 0,5\% dengan cara menimbang 0,25 gram NaCMC dikembangkan kedalam $50 \mathrm{~mL}$ aquadest. Suspensi obat asam traneksamat dibuang dengan membuat larutan stok dengan konsentrasi $1,3 \mathrm{mg} / 20 \mathrm{~g}$ BB dengan menimbang asam traneksamat sebanyak 37,798 mg kemudian di dispersikan kedalam $10 \mathrm{~mL}$ larutan NaCMC $0,5 \%$.

\section{Penyiapan Hewan Uji dan Pengujian Waktu Perdarahan}

Hewan uji yang digunakan adalah mencit (Mus musculus) yang berumur 2-3 bulan dengan bobot 20-30 gram, sebanyak 25 ekor yang terlebih dahulu diadaptasi dengan lingkungan selama 1 minggu. Pengujian dilakukan dengan memberikan suspensi asam traneksamat pada kelompok kontrol positif, suspensi NaCMC 0,5\% pada kelompok kontrol negatif dan ekstrak etanol keji beling (Strobilanthes crispus) pada kelompok uji secara oral menggunakan sonde. Kemudian mencit dimasukkan ke dalam holder, ekor mencit diberi tanda sepanjang $2 \mathrm{~mm}$ dari ujung ekor. Selanjutnya dilakukan pengujian dengan melukai bagian ekor mencit dengan scissors sterile (gunting bedah). Darah yang menetes diserap dengan kertas saring. Ukur waktu mulai darah pertama kali menetes sampai berhenti menetes pada kertas saring yang ditandai dengan tidak adanya darah yang menempel pada kertas saring. Interval waktu dari tetesan pertama hingga darah berhenti menetes adalah waktu perdarahan. Kelompok 2 yang merupakan kelompok kontrol positif dioralkan suspensi obat asam traneksamat, selanjutnya diberikan perlakuan yang sama. Kelompok 3, kelompok 4 dan kelompok 5 yang merupakan kelompok uji dioralkan ekstrak daun keji beling dosis $\mathrm{A}$, dosis $\mathrm{B}$, dan dosis $\mathrm{C}$ dan selanjutnya diberikan perlakuan yang sama. Diukur waktu perdarahan pada jam ke-0, jam ke-1, jam ke-2, jam ke-3, jam ke-4, dan jam ke-5.

\section{HASIL DAN PEMBAHASAN}

\section{Hasil Penelitian}

Analisis normalitas data yang dilakukan dengan uji Shapiro-Wilk menunjukkan bahwa sebaran data adalah normal karena nilai $\mathrm{p}>0,05$. Analisis homogenitas dilakukan dengan uji varians (Levene's test of varians) menunjukkan bahwa data homogen karena nilai $\mathrm{p}>0,05$. Analisis komparatif data antar dosis dengan waktu perdarahan dilakukan dengan Anava Dua Arah karena sebaran data normal dan homogen dan dilanjutkan dengan uji BNJD.

Tabel 1 Rerata Waktu Perdarahan Tiap Kelompok

\begin{tabular}{lccr}
\multicolumn{1}{c}{ DOSIS } & Mean & N & Std. Deviation \\
\hline KONTROL POSITIF & 92.2222 & 18 & 7.95247 \\
KONTROL NEGATIF & 99.1111 & 18 & .83235 \\
DOSIS A & 94.1111 & 18 & 5.50816 \\
DOSIS B & 88.6111 & 18 & 9.42549 \\
DOSIS C & 91.3333 & 18 & 6.81693 \\
\hline Total & 93.0778 & 90 & 7.49866 \\
\hline
\end{tabular}

Tabel 1 menunjukkan rerata waktu perdarahan pada kelompok kontrol negatif sebesar $99.111 \pm 0.832$ detik; kelompok kontrol positif sebesar $92.222 \pm 7.952$ detik; kelompok uji 
ekstrak etanol daun keji beling dosis A sebesar $94.111 \pm 5.508$ detik; dosis B sebesar $88,611 \pm 9,425$ detik; dosis $\mathrm{C}$ sebesar 91,333 \pm 7,498 detik

Grafik 1

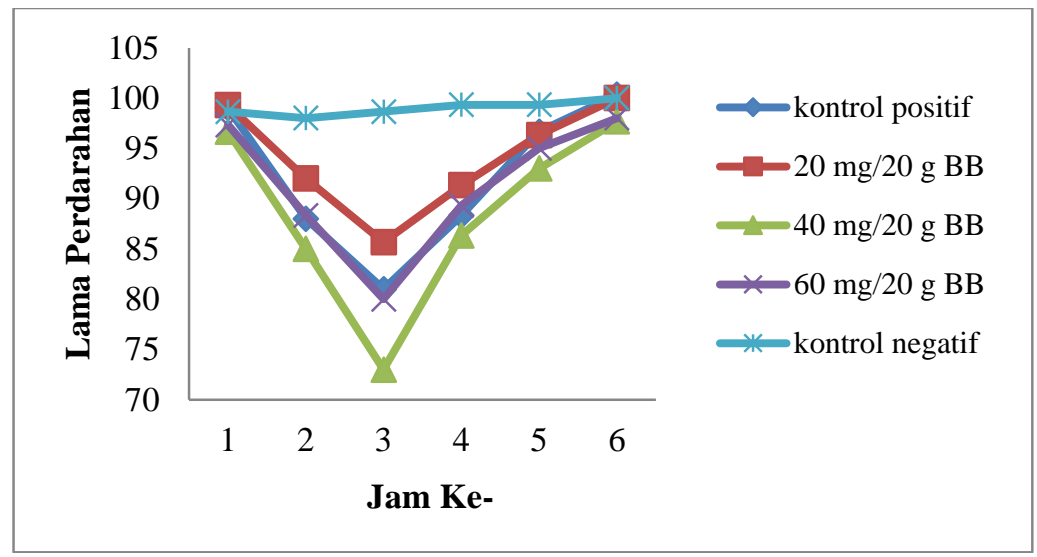

Grafik 1 menunjukkan bahwa semua variasi dosis ekstrak etanol daun keji beling memiliki efek hemostasis dengan memperpendek waktu perdarahan.

Tabel 2 Uji Normalitas

\begin{tabular}{llrrr}
\hline \multirow{2}{*}{ DOSIS } & & \multicolumn{3}{c}{ Shapiro-Wilk } \\
\cline { 3 - 5 } & & Statistic & Df & \multicolumn{1}{c}{ Sig. } \\
\hline \multirow{4}{*}{ HEMOSTASIS } & .962 & 18 & .643 \\
& KONTROL POSITIF & .797 & 18 & .100 \\
& DOSIS A & .927 & 18 & .172 \\
& DOSIS B & .935 & 18 & .237 \\
& DOSIS C & .909 & 18 & .084 \\
\hline
\end{tabular}

Tabel 2 menunjukkan hasil uji normalitas Shapiro-Wilk untuk krlompok kontrol negatif probabilitasnya 0,100 ; kontrol positif 0,643 ; dosis A 0,172 ; dosis $\mathrm{B} 0,237$; dosis $\mathrm{C} 0,084$. Hal ini berarti distribusi waktu perdarahan semua kelompok adalah normal karena probabilitasnya lebih besar dari 0,05 .

Tabel 3 Uji Homogenitas

\begin{tabular}{rrrrrr}
\hline & Levene Statistic & df1 & df2 & \multicolumn{1}{l}{ Sig. } \\
\hline HEMOSTASIS & 3.659 & & 4 & 85 & .160 \\
\hline
\end{tabular}

Tabel 3 menunjukkan nilai Levene test hitung adalah 1,120 dan nilai probabilitas adalah 0,311 yaitu diatas 0,05 yang berarti kelima variasi populasi homogen. 
Tabel 4 Hasil Uji Anava Dua Arah

\begin{tabular}{lrrrrr}
\hline \multicolumn{1}{c}{ Source } & $\begin{array}{c}\text { Type III Sum } \\
\text { of Squares }\end{array}$ & df & Mean Square & \multicolumn{1}{c}{ F } & \multicolumn{1}{c}{ Sig. } \\
\hline Corrected Model & $4423.122^{\mathrm{a}}$ & 29 & 152.521 & 15.742 & .000 \\
Intercept & 779712.544 & 1 & 779712.544 & 80474.919 & .000 \\
DOSIS & 1101.511 & 4 & 275.378 & 28.422 & .000 \\
WAKTU & 2607.656 & 5 & 521.531 & 53.828 & .000 \\
DOSIS * WAKTU & 713.956 & 20 & 35.698 & 3.684 & .000 \\
Error & 581.333 & 60 & 9.689 & & \\
\hline Total & 784717.000 & 90 & & & \\
Corrected Total & 5004.456 & 89 & & & \\
\hline
\end{tabular}

Hasil analisis dengan menggunakan Anava dua arah antara waktu perdarahan dengan variasis dosis diperoleh $\mathrm{F}$ hitung $=15,742$ dan nilai signifikansi adalah 0,000 yang artinya terdapat perbedaan yang bermakna pada pemberian variasi dosis ekstrak etanol daun keji beling terhadap waktu perdarahan. Selanjutnya untuk analisis waktu pengukuran terhadap waktu perdarahan diperoleh $\mathrm{F}$ hitung $=53,828$ dan nilai signifikan adalah 0,000 artinya terdapat pengaruh yang bermakna waktu pengukuran terhadap waktu perdarahan. Untuk menghubungkan antara dosis terhadap waktu pengukurn diperoleh $\mathrm{F}$ hitung $=3,684$ dan nilai signifikan adalah 0,000 yang artinya terdapat hubungan yang bermakna antara dosis dan waktu pengukuran terhadap waktu perdarahan.

Tabel 5 Analisis BNJD Waktu Perdarahan Antar Kelompok

\begin{tabular}{lrrrrr}
\hline \multicolumn{1}{c}{ DOSIS } & \multirow{2}{*}{$\mathrm{N}$} & \multicolumn{5}{c}{ Subset } \\
\cline { 3 - 7 } & & 1 & 2 & 3 & 4 \\
\hline DOSIS B & 18 & 88.6111 & & & \\
DOSIS C & 18 & & 91.3333 & & \\
KONTROL POSITIF & 18 & & 92.2222 & 92.2222 & \\
DOSIS A & 18 & & & 94.1111 & \\
KONTROL NEGATIF & 18 & & & & 99.1111 \\
\hline Sig. & & 1.000 & .395 & .074 & 1.000 \\
\hline
\end{tabular}

Hasil uji lanjutan menunjukkan bahwa: Rerata waktu perdarahan kelompok negatif berbeda secara bermakna dengan kelompok kontrol positif dan kelompok uji dosis A, dosis B serta dosis C. Rerata waktu perdarahan kelompok kontrol positif tidak berbeda bermakna dengan kelompok uji dosis A dan dosis C. Rerata waktu perdarahan kelompok uji B berbeda bermakna dengan kelompok kontrol negatif, kelompok kontrol positif, kelompok uji dosis A dan dosis C.

Tabel 6 Analisis Uji T

\begin{tabular}{llrrrr}
\hline \multicolumn{1}{c}{ DOSIS } & N & Mean & $\begin{array}{c}\text { Std. } \\
\text { Deviation }\end{array}$ & $\begin{array}{c}\text { Std. Error } \\
\text { Mean }\end{array}$ \\
\hline \multirow{2}{*}{ HEMOSTASIS } & KONTROL & 18 & 92.2222 & 7.95247 & 1.87442 \\
& $\begin{array}{l}\text { POSITIF } \\
\text { DOSIS B }\end{array}$ & 18 & 88.6111 & 9.42549 & 2.22161 \\
\hline
\end{tabular}


Independent Samples Test

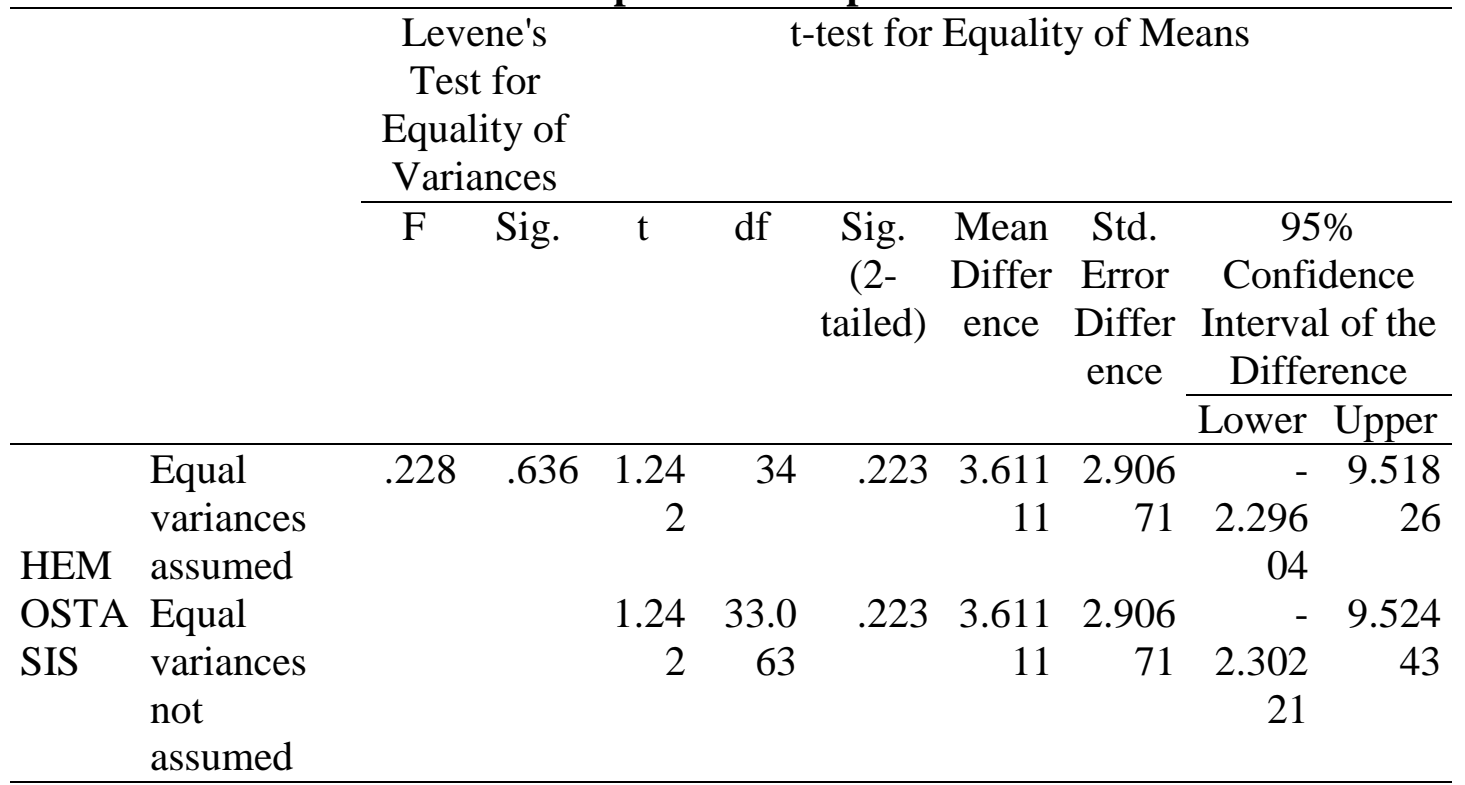

Berdasarkan hasil uji $\mathrm{T}$ diperoleh nilai sig. (2-tailed) 0,223 > 0,05 maka dapat disimpulkan bahwa tidak terdapat perbedaan yang bermakna antara kelompok kontrol positif dengan kelompok uji ekstrak etanol daun keji beling dosis B.

\section{Pembahasan}

Waktu perdarahan kelompok kontrol positif lebih pendek dibandingkan dengan kelompok negatif. Hal ini disebabkan adanya pemberian asam traneksamat yang berfungsi sebagai zat hemostatik. Asam traneksamat merupakan penghambat bersaing dari aktivator plasminogen dan penghambat plasmin. Asam traneksamat bekerja dengan cara memblok ikatan plasminogen dan plasmin terhadap fibrin.

Kelompok uji ekstrak etanol daun keji beling dosis A, dosis B dan dosis C menghasilkan rerata waktu perdarahan lebih pendek dari pada rerata waktu perdarahan kelompok kontrol negative. Hal ini disebabkan adanya zat dalam kandungan ekstrak etanol daun keji beling yang berfungsi sebagai hemostatik yaitu tannin. Tannin berkerja sebagai vasokonstriktor melalui efek astringennya akan membantu proses hemostasis tubuh dengan cara mengurangi sekresi dan permeabilitas kapiler, kontraksi ruang antar sel, pengerasan endothelium kapiler dan membentuk lapisan pelindung sehingga lapisan superfisial sel akan mengencang dan menyusut serta menghasilkan vasokontriksi local kapiler (Tedjasulaksana, 2013).

Tannin juga dapat mempercepat keluarnya protein dari sel dan mengendapkan protein darah sehingga dapat menginduksi sintesis tromboksan A2 yang dapat meningkatkan agregasi platelet, sehingga mempercepat pembentukkan sumbat platelet sementara pada pembuluh darah yang luka (Odukoya, 2009).

Waktu perdarahan yang memendek pada kelompok uji ekstrak etanol daun keji beling ini dapat disebabkan dengan adanya zat aktif lain yang terkandung didalam daun keji beling seperti flavonoid yang dapat membantu memperpendek waktu perdarahan yang bekerja secara sinergis dengan tannin. Waktu perdarahan pada kelompok kontrol positif dan kelompok uji dengan variasi dosis berbeda secara bermakna dengan kelompok kontrol negatif yang artinya obat asam traneksamat dan ekstrak etanol daun keji beling dapat mempengaruhi waktu perdarahan dengan memperpendek waktu perdarahan. Waktu 
perdarahan merupakan salah satu parameter pengukuran pembekuan darah dan ini dipakai sebagai salah satu pemeriksaan penyaring terhadap faal hemostasis.

Berdasarkan hasil uji lanjutan BNJD waktu perdarahan terhadap dosis ekstrak etanol daun keji beling menunjukkan bahwa dosis $\mathrm{A}$, dosis $\mathrm{B}$ dan dosis $\mathrm{C}$ berbeda bermakna dengan kontrol negatif yang menandakan semua dosis ekstrak memiliki efek sebagai hemostasis. Rerata waktu perdarahan kelompok kontrol positif tidak berbeda bermakna dengan kelompok uji dosis A dan dosis C. Rerata waktu perdarahan kelompok uji B berbeda bermakna dengan kelompok kontrol negatif, kelompok kontrol positif, kelompok uji dosis A dan dosis C. Maka dari data yang diperoleh dapat disimpulkan bahwa dosis terbaik ekstrak etanol daun keji beling adalah Dosis B.

Potensi efek hemostasis ekstrak etanol daun keji beling diartikan sebagai kemampuan ekstrak etanol daun keji beling menghentikan perdarahan dengan parameter waktu perdarahan yang singkat pada mencit dibandingkan dengan kontrol positif asam traneksamat. Hasil penelitian menunjukkan bahwa waktu perdarahan ekstrak etanol daun keji beling dosis B lebih cepat dibandingkan dengan kontrol positif asam traneksamat dosis $1,3 \mathrm{mg} / 20 \mathrm{~g}$ BB. Selanjutnya data dianalisis menggunakan uji $\mathrm{T}$ untuk mengetahui

perbedaan ekstrak etanol daun keji beling dosis B dibandingkan dengan kontrol positif asam traneksamat. Hasil uji $\mathrm{T}$ menunjukkan bahwa tidak terdapat perbedaan yang bermakna antara kelompok kontrol dengan kelompok uji ekstrak etanol daun keji beling. Hal ini menunjukkan bahwa ekstrak etanol daun keji beling dosis B memiliki efek hemostasis sama dengan obat asam traneksamat.

\section{KESIMPULAN}

Kesimpulan dari penelitian ini adalah ekstrak etanol daun keji beling dapat memperpendek waktu pendarahan pada mencit serta memiliki potensi yang sama dengan kontrol positif, dimana dosis B merupakan dosis terbaik dari ekstrak etanol daun keji beling sebagai hemostasis.

\section{DAFTAR PUSTAKA}

1. Setiadinata Jimmy. 2003. Penanggulangan perdarahan. Bandung: FK UNPAD

2. Vogel, G.G. 2002. Drug Discovery and Evaluation: Pharmacological Assays. ${ }^{\text {nd }}$ Ed. Berlin : Springer

3. Sukandar, E.Y., Sigit J.I., Fitriyani, N. 2008. Efek Antiagregasi Platelet Ekstrak Air Bulbus Bawang Putih (Allium sativum L.,), Ekstrak Etanol Rimpang Kunyit (Curcuma domestica Val.) dan Kombinasi Pada Mencit Jantan Galur Swiss Webster. Majalah Farmasi Indonesia, 19 (1).

4. Pedersen W Gordon. 1996. Kelanjutan dan komplikasi pencabutan gigi. Dalam: Lilian Yuwono, editor. Buku ajar praktis bedah mulut. Jakarta: Penerbit Buku Kedokteran EGC;

5. Setyaningsih, D. 2008. Uji Efek Infusa Daun Keji Beling Terhadap Penurunan Kadar Glukosa Darah Kelinci Jantan. Universitas Muhammadiah. Surakarta.

6. Li, K, Diao, Y, Zhang, H, Wang, S, Zhang, Z, Yu, B, Huang, S \& Yang, H. 2011. Tannin Extracts From Immature Fruits of Terminalia Chebula Fructus Retz. Promote Cutaneous Wound Healing in Rats, BMC Complementary and Alternative Medicine, vol. $11 ; 1$ - 9 .

7. Al-Henhena, N, Mahmood, A, Al-Magrami, A, Nor Syuhada, ABN, Zahra, AA, Summaya, MD, Suzi, SM \& Salmah, I. 2011. Histological Study of Wound Healing Potential by Ethanol Leaf Extract Strobilanthes crispus in Rats. Journal of Medicinal Plants Research, vol. 5; 3660 - 3666. 
8. Tedjasulksana, Regina. 2013. Ekstrak Etil Asetat dan Etanol Daun Sirih (Piper betle L.) Dapat Memperpendek Waktu Pendarahan Mencit (Mus musculus). Jurnal Kesehatan gigi. Vol. 1 No. 1.

9. Odukoya, O.A., Sofidiya, M.O., Ajadotuigwe, J.O., Olaleye, O.O. 2009. Hemorrhoid Theraphy with Medical Plants: Astringency and Inhibition of Lipid Peroxidation as Key Factors. International Journal of Biological Chemistry, 3: 111-118 